[PG1]

\title{
Power, nobility and charity: the case of morgado-chapel and the hospital of the Barros family in Braga, (Portugal.)
}

\author{
Luís Gonçalves Ferreira, Lab2PT/University of Minho, Portugal; \\ luis.ferreira.f@gmail.com
}

The Barros family, has, for centuries, administered the morgado of Real, the chapel of Senhora da Graça and a hospital in the city of Braga that harboured poor women. This hospital, named the Hospital de Santiago and the Hospital das Velhas (hospital for elderly women), was founded in the Late Middle Ages and continued to function until the 19th century. The current study analyses how aid to the poor, in an urban context, served as a catalyser of the prestige of the family that administered it. Using manuscript, printed and iconographic sources, processed by a multidisciplinary methodology, this investigation discusses the main patrimonial, social and symbolic coordinates that allowed the survival of the morgado and of the hospital in the long term.

Keywords: Hospitality; nobility; power; urban history; poor-relief; gender history; charity; history of hospitals

\section{Introduction}

In 1524, the Braga Chapter identified its houses at 16, Rua do Poço / Santa Maria ${ }^{1}$ with the Hospital de Santiago, on its south $\operatorname{side}^{2}$. In 1830, the priest from the parish of Cividade recorded the death of Joana da Conceição, a girl aged between eight to nine years old, daughter of Teresa Maria de Jesus, a resident of the Hospital das Velhas of the same parish ${ }^{3}$. In a testimony gathered, before the existence of the law to abolish chapels and morgados issued by the constitutional monarchy (1863), ${ }^{4}$ the memoirist Bernardino José de Senna ${ }^{5}$ indicates that, in Cividade, "existed the Hospital de Santiago, known as "of the elderly women", administered by the morgado of Real. Apart from these references, the institution has dwelled in almost four centuries of silence and has been completely unknown until today.

This article highlights the results of an investigation ${ }^{6}$ to gather, process and problematize the historiographic presentation of Hospital de Santiago. As there is no 
This is an Accepted Manuscript of an article published by Taylor \& Francis in INTERNATIONAL JOURNAL OF REGIONAL AND LOCAL HISTORY on 07 of November of 2021 available online: https:/www.tandfonline.com/doi/full/10.1080/20514530.2021.1988613

known documentation of an institutional nature, this paper is based on references from indirect sources, that have been interpreted according to a multidisciplinary methodology, ${ }^{7}$ working with both iconographic sources (maps and cartography) and manuscript and printed sources (parish records, revenue and expense books, contracts, dictionaries, genealogy books or memoirs). This article presents an intersection of the realities of the rich and of the poor, discussing, on the one hand, a lineage concerned with the memory and salvation [PG2] of the soul of their ancestors; and on the other hand the poor that, throughout these centuries, have relied on the resources of this hospital to ensure their survival.

This examination follows a tripartite structure: in the first instance, it will highlight the historiography, presenting prior references to the institution and framing the issues in the data. In the second part, it will focus on the first evidential link present in a contract from the 16th century that adds assets to the primordial morgado ${ }^{8}$. Finally, it will analyse the reform of the 16th century, that established the morgado of Real and steered the destinies of the hospital during the Early Modern Age.

\section{Places, debates and questions}

Some historians have referred to, in the context of work on medieval aid ${ }^{9}$, an institution recognisable as the Hospital de Santiago, in Braga. Alberto Feio ${ }^{10}$ mentioned that, near Colégio de São Paulo (school), a hospital for women was founded, that was originally named the Albergaria Nova da Cividade (inn). This establishment would later receive the name "Hospital das velhas". José Marques ${ }^{11}$ emphasized that the Hospital de Santiago coexisted, in the late Middle Ages, with two other similar institutions, that would be integrated by the Archbishop Diogo de Sousa into the Hospital de São Marcos. Albergaria de São Tiago was one of nine inns in the city ${ }^{12}$. The same historian ${ }^{13}$, in a study about the veneration of São Tiago (Saint James), in the north of Portugal, revealed that the inn, in the middle of the 13th century, was already functioning because it received monetary support from the inheritance of a canon. In a review article about the Minho Region in the Late Middle Ages, José Marques ${ }^{14}$ recapitulated this previous data.

Over the past decade, Maria do Carmo Ribeiro ${ }^{15}$, through an approximate mapping, ascribes Albergaria de São Tiago to a locality that this paper argues was the location of the hospital of the Barros Family. Albergaria Nova da Cividade was still located inside the city walls, but near the window of Cividade, in the extreme southeast of the medieval wall. Hospital de Santiago is treated separately from these inns and they 
This is an Accepted Manuscript of an article published by Taylor \& Francis in INTERNATIONAL JOURNAL OF REGIONAL AND LOCAL HISTORY on 07 of November of 2021 available online: https:/www.tandfonline.com/doi/full/10.1080/20514530.2021.1988613

were identified as different institutions. Leonardo Manuel Cabral da Silva ${ }^{16}$, in his research on medieval hospital architecture, integrated the references of Marques, Feio and Ribeiro. However, none of these studies connected the name of the Barros family with an hospital/inn, active, in the city of Braga during the medieval and early modern periods. These historiographical references are scattered and, sometime, conflicting. This situation can be explained by the nature of the sources, the proliferation of brotherhoods, inns, hospitals, leper colonies or leper hospitals in the urban fabric and by the vast scope of the term "hospital". The news that this medieval hospital/inn had remained active throughout the Early Modern Age, in addition to the other welfare outlets present in Braga for that period has not hitherto been recognised ${ }^{17}$. The data regarding its precise location, the names of its founder and administrators, its articulation with an entailed estate/chapel and the extent of the aid it provided are also new.

Due to the inconsistencies regarding the sources, and the methodology based on indirect references that these inconsistencies imposed on this study, the answers presented here, although well-documented, still leave many questions to answer. In this sense, this text is a template for other studies. The perception of this institution can be complemented with the discovery of new documents or by the reinterpretation of the references presented here. The exact date of foundation and the social provenance of its founder are [PG3] unknown (see Figure 1), which has prevented some important conclusions. The social conditions of the transfer of power between the different generations of the family, the possible property endowments made by each one of them and how the matrimonial strategies that guaranteed the continuity of the lineage and the sustenance of their charitable project remain unknown. 


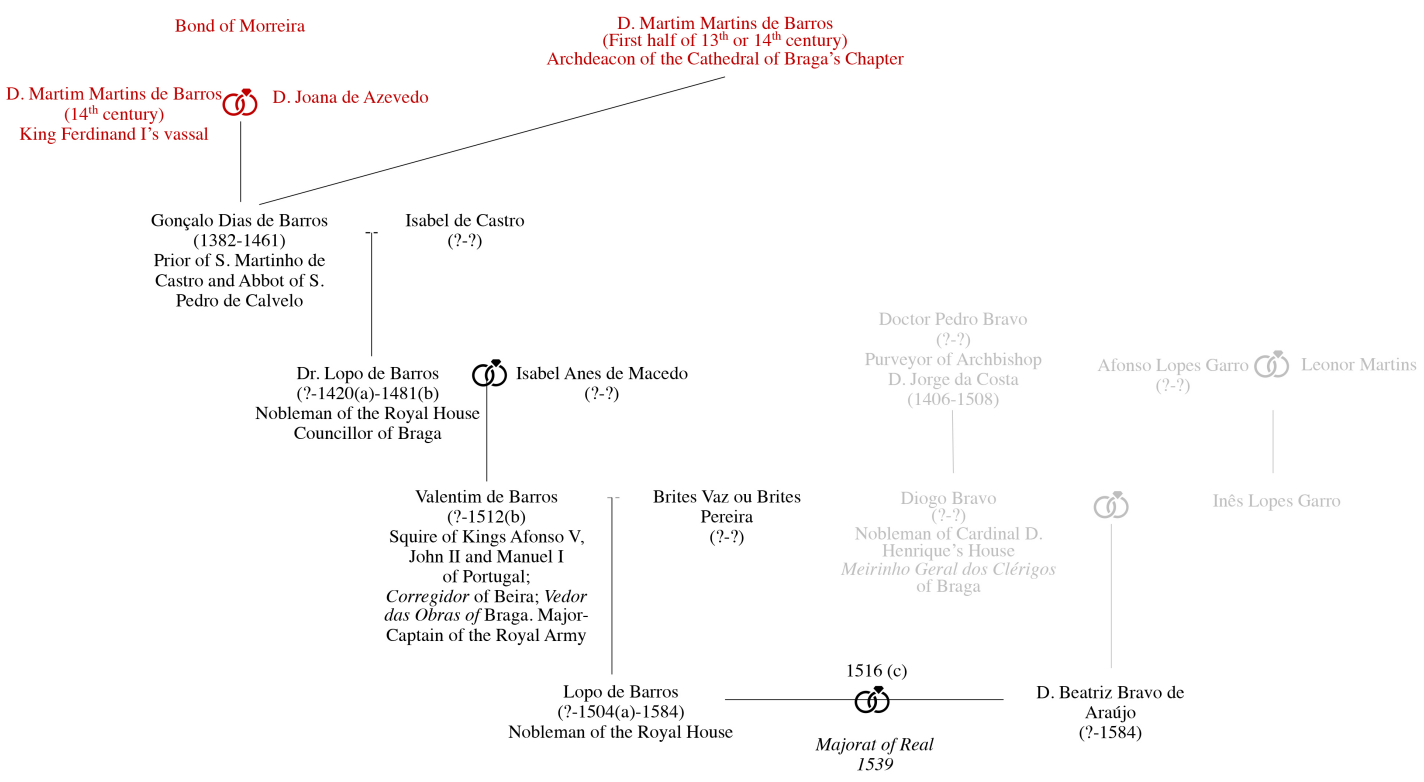

Figure 1. Barros Geneology, $13^{\mathrm{t} /} / 14^{\mathrm{th}}-16^{\text {th }}$ centuries. Source: Domingos de Araújo Affonso, «Da verdadeira origem de algumas famílias ilustres de Braga e seu termo. XVIII Barros de São Jerónimo de Real», Bracara Augusta XXIV, n. 5758 (69-70) (1970): 124-130; ADB, Manuscritos, Tomo 4. ${ }^{\circ}$, Memórias Genealogicas de Braga Extrahidas de diversos authores verídicos e copiados por hum Anonimo fiel e verdadeiro, século XVIII, n. ${ }^{\circ}$ 978,ff. 193-197v. e255-267v. ANTT, Chancelaria de D. Afonso V, Livro 3, 1438-1481, n. ${ }^{\circ}$ 3, f. 47; ANTT, Genealogias Manuscritas, Famílias Bracarenses ou Memórias Genealógicas de algumas familias do Minho e Trás-os-Montes, 1784, Tomo 1, n. ${ }^{\circ}$ 21, ff. 1-7; Felgueiras Gaio,Nobiliário de Famílias de Portugal, ed. Agostinho de Azevedo Meirelles e Domingos de Araújo Affonso, vol. Tomo VI (Braga: Oficinas Gráficas da «Pax», 1938), 158. Caption: (a) Date of legitimisation; (b) Date of the will; (c) Deed of endowment.

This article adds to the historiography on the "very meaningful number of small institutes referred to as hospitals which continued to be very similar to the medieval 'hospitals" mentioned by Laurinda Abreu ${ }^{18}$. These institutions are common in all of the Iberian 'assistance networks' during the Early Modern Age ${ }^{19}$ and they are less studied possibly because they are poorly documented. Hospital de Santiago withstood the grave crisis of welfare institutions' disorganisation at the end of the Middle Ages $^{20}$, the incorporation process led by the Crown with the Hospital de Todos os Santos (1492) as an example and from the chapel regulation directives (1514). This hospital was founded on the assumptions of secular spirituality that inspired the fraternal movement, the exercise of individual charity and the creation of private aid institutions during the Late Middle Ages and Early Modern Age. The belief in the effectiveness of charity in the salvation of the soul of the benefactors maintained the intentions of the founder of Hospital de Santiago. Hospitals continued to be symbols of power in the interest of the elites $^{21}$. These institutions had a recognized social relevance ${ }^{22}$ and framed relevant 
This is an Accepted Manuscript of an article published by Taylor \& Francis in INTERNATIONAL JOURNAL OF REGIONAL AND LOCAL HISTORY on 07 of November of 2021 available online: https://www.tandfonline.com/doi/full/10.1080/20514530.2021.1988613

patrimonial ties. Chapels remained places of public perpetuation of personal and group influence and of authority of the memory of the founder's name and of the ancestors ${ }^{23}$. In this regard, chapels and aid [PG4] institutions converge in the maintenance of the nobility based on the hierarchical logic of Early Modern Age societies founded on the importance of the gift ${ }^{24}$.

Giving and receiving, as public events, engaged client networks and sympathies; the management of poverty recognized and maintained social hierarchies ${ }^{25}$. Matrimonial strategies, throughout centuries, also, managed of the memory and assets of the Barros' souls ${ }^{26}$. Regarding the aided, although the hospital was maintained as a house where, at least, poor women were sheltered, following the determinations of the founder, this institution seems to have evolved to focus on "elderly women", as poor people incapable of earning a living by their own efforts. In this regard, the elderly women and/or widows were considered worthy of receiving assistance by the early modern assistance networks developed to purge from the assistance system the 'false' poor who did not deserve alms. This circumstance allows a glimpse at an institution that adapted its charitable goals, to a particular urban space under the tutelage of an ecclesiastical master ${ }^{27}$. The project of the Barros family seems to have only succumbed to the force of the law of the constitutional monarchy that abolished the morgados and the chapels, in the second half of the 19th century $^{28}$. Throughout this very broad time period, the "hospital" remained a pious instrument and element of affirmation of family power based in the seniority of its lineage, answering the specific needs of the poor population served.

Hospital de Santiago was integrated in a morgado-chapel ${ }^{29}$ of the Barros family of Real. The constitution of this link is based on two founding bonds (see Figure 1): the first, is of medieval origin, the "bond of Morreira", and was instituted by Martim Martins de Barros; a second bond, from April of 1539, named "Morgado de Real", added assets to the first and was a symbolic re-foundation.

\section{The bond of Morreira, Capela de Nossa Senhora da Graça and Hospital de Santiago}

Too little is known of Martim Martins de Barros - either the Archdeacon of Braga $^{30}$ or a descendent of a nobleman from Barros, in Regalados. ${ }^{31}$. Sometime during the prelature of Archbishop Estêvão de Sousa (p. 1212-1228) ${ }^{32}$ or in the course of the 14 th century $^{33}$, this man formed a bond, headquartered in some houses on Rua do Paimanta, in the city of Braga, and in the properties of the Parish of Vila Cova de 
This is an Accepted Manuscript of an article published by Taylor \& Francis in INTERNATIONAL JOURNAL OF REGIONAL AND LOCAL HISTORY on 07 of November of 2021 available online: https://www.tandfonline.com/doi/full/10.1080/20514530.2021.1988613

Morreira.. The properties provided for the maintenance of a chapel and for a weekly mass for his soul, celebrated at the shrine of Senhora da Graça, beside his grave, located at the central nave of the cathedral, next to the south entrance. The founder's grave and the chapel were oriented towards the assets that made up the bond (see Figure 1). The foundation of the Hospital de Santiago was part of the bond, as "it was commissioned [to the successors of Morgado of Real] the Hospital de Santiago erected by those who first founded the [old] morgado" 34

As can be seen in Figure 2, the building of the hospital integrated a set of family assets, that, in 1539, are designated as property of the old morgado (bond of Morreira). Besides the three houses ${ }^{35}$ on Rua de São Tiago ${ }^{36}$, where the institution operated, this hub included two ground-floor houses and one traditional barn, on Rua de Palhas, some big houses and three adjacent plots of land, connected through an internal door, on Rua de Paimanta, and two adjacent houses, located to the right of the front door, both facing Rua Pequena. The morgado of Real paid an annual censo $^{37}$ of 54 réis for the [PG5] bigger houses $^{38}$. Besides the properties on Rua Pequena and on the north side of Rua de Paimanta, that were physically separated from the others, the houses were "surrounded all around by their yard and orange tree garden and well" 39 . In fact, this space is perceptible on the map of George Braun (1594), on a map of the 17 th century ${ }^{40}$, on the map of André Soares (1756-1757) ${ }^{41}$ and on the cartography of the 18th century ${ }^{42}$. 


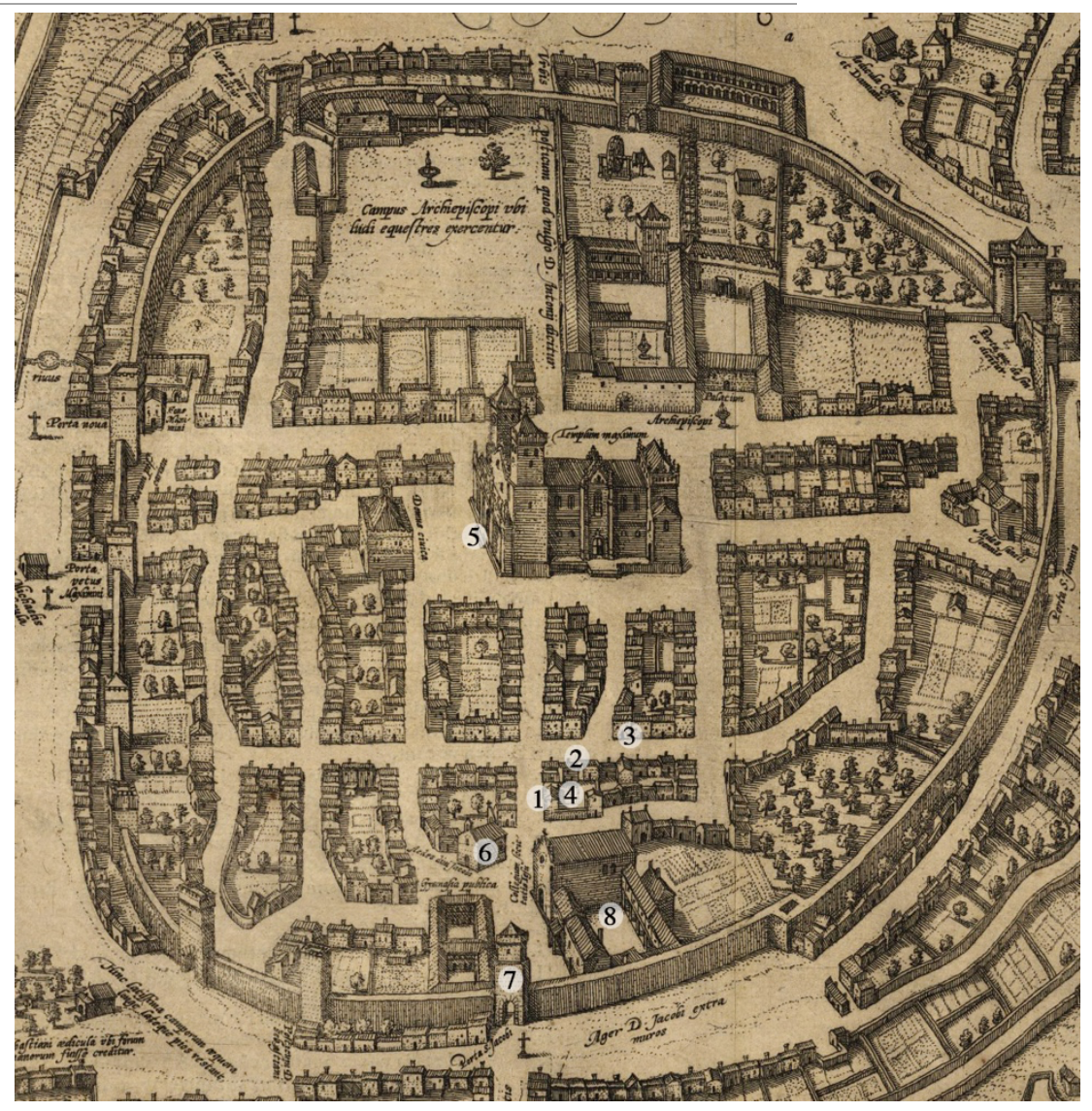

Figure 2. Intramural Braga at the end of the $16^{\mathrm{th}}$ century. Source: ADB, Quinta de Real, Requerimento do Excelentíssimo Visconde do Amparo..., ff. 2-4v; ADB, Índice dos Prazos do Cabido, século XVIII, n. ${ }^{\circ}$ 1, f. 248; Nova Bracarae Auguste descriptio de George Braun, 1594. Caption: 1 - Hospital de Santiago; 2-House of the Chapter with perpetual jurisdiction to Morgado of Real and large two-story houses to the east of these; 3 - Townhouses facing Rua do Pai Manta and Rua Pequena; 4 - Yard, orange grove, well, haystack and single storey houses (south) of the Barros family 5 - Sé of Braga (cathedral); 6 - Church of São Tiago of Cividade; 7 - Porta de São Tiago (gate); 8 - Colégio da Companhia de Jesus (school).

The zone where the set of properties of the Barros family was located was at the core of medieval Braga, whose urban structure resulted from the interception of the perimeters of the roman and medieval defensive systems ${ }^{43}$. Next to one of the main gates and fields of the city (titled São Tiago), the hospital was, as Figure 3 illustrates, a medieval assistance institution typical of Portuguese urban spaces. These were simple constructions and without markings to distinguish them from the other buildings with lesser rooms used as housing. Normally, these were located near important transit routes to access the city, integrated within the commerce and pilgrim routes, with areas or terrains used for the production of goods for self-consumption (wells, backyards, orange tree gardens, patios or porches $)^{44}$. It is not clear if the poor people had access to the back of the building, or 
This is an Accepted Manuscript of an article published by Taylor \& Francis in INTERNATIONAL JOURNAL OF REGIONAL AND LOCAL HISTORY on 07 of November of 2021 available online: https://www.tandfonline.com/doi/full/10.1080/20514530.2021.1988613

if they occupied the whole ground-floor ${ }^{45}$. The ground floor of the building would have had an area slightly more than $100 \mathrm{~m}^{2}$. $[$ PG6]

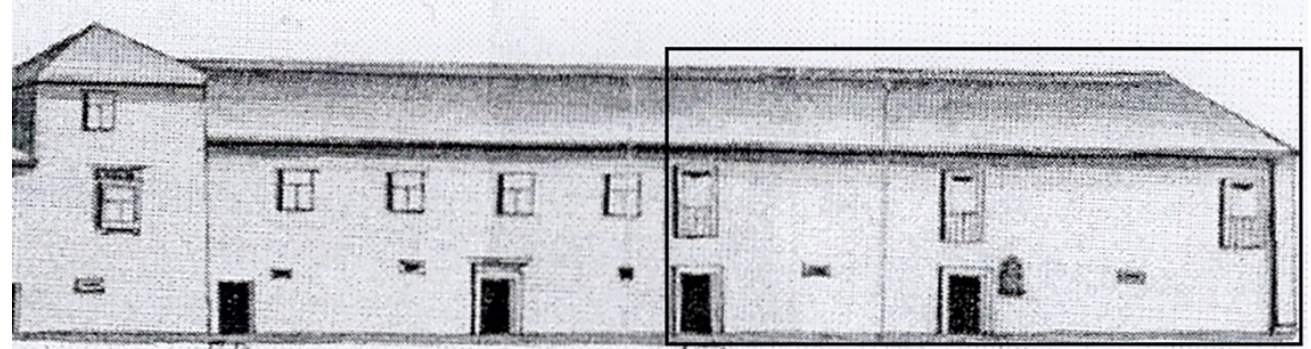

Figure 3. Hospital dos Barros in Rua de São Tiago,* 1750. Source: Mapa das Ruas de Braga, Fac-Simile Ed. (1750), vol. 1 (Braga: Arquivo Distrital de Braga e IBM Portugal, 1989), 14. * In the index of the Chapter's houses, from the 18th century, it is mentioned that Rua de São Tiago was a part of Rua do Poço that was above the Travessa (side street), which in that century was better known by the name of Rua do Poço. ADB, Índice dos Prazos das Casas do Cabido, século $X V I I I$, n. $^{\circ} 1$, f. 18 . It was also called Rua de Santa Maria.

The headquarter of these properties was located in the nerve centre of Braga's ecclesiastical power. Most properties on the streets surrounding the Sé Cathedral, belonged to the Chapter of the cathedral ${ }^{47}$. It is possible that Martim Martins de Barros used his position in the hierarchy of Braga and in the Chapter to acquire these properties. By looking at the noble families of the Late Middle Ages, it is possible to locate an origin for the founder, in the noble strata of "infanções" 48 created in the context of the reconquest. In accordance with the system of pure lineage, which, with the morgado, would come to assert itself from the 13th century onwards, the fixation on agnatic transmission of property imposed celibate careers, especially clerical, on secondary children. On the other hand, the cognitive system, which in Portugal endured through the permanent state of war related to the re-conquest, favoured the proliferation of secondary lineages, whose nickname was established by place names of villages or small towns ${ }^{49}$. Martim Martins de Barros might be such a second-born son of a family, his autonomous lineage project based on succession through the male line and primogeniture. ${ }^{50}$ The 1539 contract suggests that the succession of the morgado of Real was based on the assumptions established in the old bond of Morreira. Diogo de Barros, male, firstborn, legitimate and natural son of the re-founders, should succeed in this way "as in the old morgado" 51 . This succession model developed in Portugal in the 11th century, it was affirmed at the beginning of the 14th century and was consolidated in medieval Portuguese morgados ${ }^{52}$. Alms, chapels, masses and the donation had their specific pious dimension, seeking to guarantee the salvation of the soul, but they were also mechanisms for proclaiming 
This is an Accepted Manuscript of an article published by Taylor \& Francis in INTERNATIONAL JOURNAL OF REGIONAL AND LOCAL HISTORY on 07 of November of 2021 available online: https:/www.tandfonline.com/doi/full/10.1080/20514530.2021.1988613

authority and personal and group wealth ${ }^{53}$. The triumph of the idea of purgatory, which counted on the contributions of scholastics, Franciscans and Dominicans ${ }^{54}$ that prescribed physical acts of a sacral nature for efficacy in the liberation of the soul from its captivity, are central to the new religiosity that developed, throughout Europe, from the 11th century onwards. In comparison to the Benedictine monastic experiences of the previous period, which were markedly elitist, the changes of the Late Middle Ages imposed a saving capacity on the actions of the laity. The creation of military religious orders, the phenomenon of urban confraternities, the centrality attributed to the experiences of acts of charity (such as almsgiving to the poor), penance (fasts and flagellations), [PG7] pilgrimages, the cult of relics and the Eucharist, and the experiences of miracle and grace, are counted among the aspects of the sensorial spiritual experience that allowed ordinary men and women to glimpse holiness and the divine ${ }^{55}$.

The understanding of disease itself was driven by convictions linked to the immaterial and the mystical field: "for most people, the human body was a field where opposing invisible forces were engaged in permanent struggle, threatening to disturb its balance" 56 . This conviction referred to the medieval to belief in the thaumaturgical power of saints and relics. People with diverse illnesses sought sanctified places to receive protection and divine grace. The veneration of São Tiago Maior was very popular in the north of Portugal in the Middle Ages: he was the patron saint of countless churches, brotherhoods, hospitals, hostels, and fixed pilgrimage coordinates on the path to Galicia ${ }^{57}$. Based on the narratives in the Códice Calixtini (or Liber Sancti Jacobi), the apostle Tiago (James) was credited with many miracles and healing/therapeutic feats. Disciple, powerful warrior, pilgrim and battler against the Moors, the veneration of the apostle also meant, in the Middle Ages, that the virtue of hospitality and charity fundamental to material support was owed to all Christians who, deprived of their assets, decided to start a pilgrimage path. A sacred figure was believed to be an entity that established an intermediary between the devotee and the grace of $\operatorname{God}^{58}$.

The invocations to São Tiago, in the hospital, and to Nossa Senhora da Graça, in the chapel, show the spirituality of the benefactor, who practiced charity to obtain spiritual benefits from God. The veneration of the saints and the act of asking and receiving from divine entities was rooted in feudal vassalage practices ${ }^{59}$. On the Portuguese side of the road to Santiago de Compostela that passed through Braga ${ }^{60}$, some sanctuaries were sought for their healing properties. The relics of São Frutuoso, São Geraldo and São Vicente are associated with legends according to which pilgrims had 
This is an Accepted Manuscript of an article published by Taylor \& Francis in INTERNATIONAL JOURNAL OF REGIONAL AND LOCAL HISTORY on 07 of November of 2021 available online: https:/www.tandfonline.com/doi/full/10.1080/20514530.2021.1988613

been freed from afflictions, such as wounds, headaches, paralysis, leprosy, dementia, deafness ${ }^{61}$. Due to the limited nature of medical care at the time, the medieval hospital placed strong spiritual importance on the donation and exchange that converged there. Institutions of assistance aligned popular beliefs and religiosity with the spiritual experiences of the laity who associated it with the salvation of the soul.

Despite being made inferior by its dirty and sinful dimension, the body intervened in the reparation for sins through atonement practices, namely fasting, abstinence, mortification and pilgrimage ${ }^{62}$. The centrality of the sacrament of penance and confession, a fundamental part of medieval religiosity ${ }^{63}$, contributed to the deepening of the phenomenon of individualization, as they required examinations of conscience and moments of individual reflection ${ }^{64}$. This reflective and retrospective dimension of the human being acquired special relevance in the moments when it foresaw the death of the body, the imminence of divine judgment and the dangers that his soul would incur if he was not careful. Until the advent of science, death did not discontinue the existence of the human being ${ }^{65}$.

As a result of philosophical reconfiguration of the human being's place in relation to $\operatorname{God}^{66}$ and charity as a motivation for public charity ${ }^{67}$, sponsorship of a hospital was one of the actions that resulted in a relationship with the deity and in the process, protection from the suffrage of earthly sins. The "ethos" of charity standardized all medieval and modern hospital institutions, regardless of whether they were founded and/or managed [PG8] by religious or lay orders ${ }^{68}$. Hospitals, charity and poverty are inseparable concepts. Charity is love for God and helping others is an act of mercy that one feels towards others, because all human beings have God within them, and in this sense, they are tributaries of this attitude. Almsgiving is a precept derived from charity, mercy, obedience to God and penance ${ }^{69}$.

\section{Sixteenth-century re-foundation: the morgado of Real and the chapel in the cathedral's cloister}

Purgatory emerged reinforced from the reform process of the Catholic Church after the Council of Trent (1545-1563). The existence of a captivity for sinful souls explains the success of the brotherhoods that managed the assets responsible for rescuing them, such as religious orders or brotherhoods, which included the Misericórdias ${ }^{70}$. The soul's assets constituted the necessary economic base for the pursuit of the welfare purposes to which that brotherhood was committed; on the other hand, this economic base 
This is an Accepted Manuscript of an article published by Taylor \& Francis in INTERNATIONAL JOURNAL OF REGIONAL AND LOCAL HISTORY on 07 of November of 2021 available online: https://www.tandfonline.com/doi/full/10.1080/20514530.2021.1988613

gained social and cultural power through the management of the assets of the poor, carried out in a public space. The guidelines for early modern assistance were clearly defined in the Late Medieval Period ${ }^{71}$ : secular prominence based on the action of brotherhoods more or less guided by objectives of mutual assistance and strongly based on the local logic of power; reduced Church intervention; delimitation of the main institutions (chapels, hostels, hospitals, grocery stores and leper hospital); definition of the categories of those assisted (poor, foundlings, lepers, prisoners, women) based on a virtuous but sceptical vision of the poor.

Overcoming the severe crises faced by the medieval institutions during the 14th and 15 th centuries ${ }^{72}$ and despite the innovations introduced by the Crown regarding hospital care during the second-half of 15 th century and 16 th century ${ }^{73}$, the preservation of the activity of the Hospital de Santiago in the long run was due to the continuity of the pertinence of the practices of giving and receiving to the maintenance of the social order ${ }^{74}$ and the recognition that the poor had a decisive role in the salvation of the souls of the wealthier ${ }^{75}$. In the words of Maria Ângela Beirante ${ }^{76}$, "poverty helped wealth to conquer Heaven". With the advent of modernity and despite the erstwhile apparent cloak of virtue that fell on the poor in their ability to intervene with the divine, a negative counter image about poverty arose, based on the valorisation of work and the censorship of idle begging 77

In Braga, throughout the medieval period, there might have existed fourteen welfare institutions ${ }^{78}$, but only four seem to have reached the Latter Middle Ages: Hospital de Santiago, Hospital da Rua Nova, Hospital do Rocamador and a hospital for lepers ${ }^{79}$. In 1508, Diogo de Sousa, Archbishop of Braga, united the 'rents' of the brotherhoods of Rocamador, Corpo de Deus, the leper hospital and the Hospital da Rua Nova and created Hospital de São $\operatorname{Marcos}^{80}$. Being restricted territory and, therefore, immune to the power of the Crown, the incorporation process was led by its temporal master. The noble statute of the Barros family (which was based on the local prestige of the Chapter from which the old bond of Morreira was established), their capacity to maintain their lineage, and their proximity to the king, ensured that the bond of Martim Martins de Barros remained active and was strengthened in 1539.

In the Late Middle Ages and during the Early Modern period, the symbolic prerequisites of nobility associated with the influence of the quality and antiquity of the lineage [PG9] at the expense of the knight continued ${ }^{81}$. Despite not being exclusive prerogatives of nobility, the chapel morgados contributed in the reinforcement of the 
This is an Accepted Manuscript of an article published by Taylor \& Francis in INTERNATIONAL JOURNAL OF REGIONAL AND LOCAL HISTORY on 07 of November of 2021 available online: https:/www.tandfonline.com/doi/full/10.1080/20514530.2021.1988613

antiquity of the ancestors through the presence of their memory in the earthly space ${ }^{82}$. Bonded property was fundamental to the maintenance of the economic power that allowed the law of nobility to live ${ }^{83}$. Pious legacies, charity, name and lineage represented power. It was in this evident continuity of the medieval cadres and in the defence of the social status quo that Laurinda Abreu interpreted the action of organizing assistance networks. Since the beginning of the 15 th century, public authorities have played a leading role in this process throughout Europe. Monarchs, with the consent of the papacy, sought to purify the assistance structure, by integrating the heritage of poorly managed hospitals and, thus, defending the purpose of the institutes and the poor themselves, guaranteeing that they maintained access to the goods that they had been bequeathed ${ }^{84}$. At the same time, the Portuguese crown was making efforts to dominate the symbolic, economic and social mechanisms on which the authority of the nobility rested, adhering to the codes of conduct of the house and the service to the $\mathrm{king}^{85}$. The organization of assistance networks and the social hierarchy are part of the process of building the modern State.

As can be seen in Table 1, the effort to consolidate the name and power of lineages was evident in the combination of the available 'third' of the parts ${ }^{86}$ of Lopo de Barros and Beatriz Bravo de Araújo, by linking the assets they inherited from her father, Diogo Bravo, and his mother, D. Beatriz ${ }^{87}$. Portuguese inheritance law allowed a third of the assets to be freely available, keeping the remaining two parts intact as the right of the 'forced' heirs. The property in the vicinity of Braga, where the manor was located came from the female side (see figure 4) and would become the palatine representation of the family name. The commitment to strengthen the physical space of the farm or the Quinta of Real ${ }^{88}$ as a symbol of the Barros family is also evident, as two old couples are exchanged for two new ones. In memory of the commitments of the father and mother of the founders, the new Morgado of Real started a weekly mass on Saturday for each of their souls (see Table 2).

Lopo de Barros was a noble knight of the house of D. Manuel I, from whom he received an allowance and lodging, and was one of the legitimate children of Valentim de Barros, a squire of the houses of D. Afonso V, D. João II and D. Manuel I, corregedor of the judicial district of Beira and four times captain of the royal navy ${ }^{89}$ Lopo de Barros was the brother of D. Frei Brás de Barros, reformer of the Congregation of Canons Regular of Santo Agostinho, first bishop of Leiria ${ }^{90}$ and cousin of João de Barros (c. 14961570), author of the first four "Decades of Asia" "91. The destinies of Hospital de Santiago 
gravitated to this nobleman from Braga. Lopo de Barros affirms the legitimacy of strengthening his family's patrimony by referring to the kings of Portugal at various points in the contract with the Morgado of Real.

The patrimonial reinforcement would serve so that the "legitimate successors of the morgado could serve the crown of the kingdoms of Portugal", since Lopo Barros' father, grandparents and great-grandparents were "noble men and served the past kings in wars and battles and the conquest of places in Africa"92. The couple added a birthday mass to the initial bond, said on the day of kings or on the eighth day of Christmas, in memory of D. Afonso V, D. João II and D. Manuel I, of whom their parents had received many favours ${ }^{93}$ (see Table 2). The mandatory masses in the chapel of Nossa Senhora $d a$ Graça would be suspended for the duration of the service to the monarchs. These associations between the memory of the name of the Barros family and the memory of [PG 10] 
Table 1. Properties of the morgado of Real, 1539

\begin{tabular}{|c|c|c|}
\hline Designation & Location & Origin \\
\hline Big houses & $\begin{array}{l}\text { Rua do Paimanta (city of } \\
\text { Braga) }\end{array}$ & Bond of Morreira \\
\hline 2 houses with two floors & Rua Pequena ${ }^{a}$ (city of Braga) & Unknown \\
\hline 3 houses with two floors & $\begin{array}{l}\text { Rua do Paimanta (city of } \\
\text { Braga) }\end{array}$ & Bond of Morreira \\
\hline 3 houses with ground floor & $\begin{array}{l}\text { Rua de São Tiago/Rua de } \\
\text { Santa Maria }{ }^{c} \text { (city of Braga) }\end{array}$ & Bond of Morreira \\
\hline 2 houses with ground floor & Rua de Palhas ${ }^{\text {d }}$ city of Braga) & Bond of Morreira \\
\hline Traditional barn & Rua de Palhas (city of Braga) & Bond of Mo \\
\hline Houses with & Rua Verde (city of Braga) & Unk \\
\hline Big houses $^{e}$ & Rua de Sousa (city of Braga) & $\begin{array}{l}\text { Diogo Bravo, father of the } \\
\text { female institutor }\end{array}$ \\
\hline Farm named "Paço de & Cova/Morreira & Bond of Morreira ${ }^{\mathrm{f}}$ \\
\hline $\begin{array}{l}\text { Meixeira" with couples to work } \\
\text { the land (13 caretakers) }\end{array}$ & (municipality of Braga) & \\
\hline $\begin{array}{l}\text { Quinta of Granja with couples } \\
\text { to work the land from Santo } \\
\text { Estêvão ( } 3 \text { caretakers) }\end{array}$ & $\begin{array}{l}\text { Palmeira (municipality of } \\
\text { Braga) }\end{array}$ & Unknown \\
\hline $\begin{array}{l}\text { Casal Novo de Coveiro } \\
\text { caretaker) }\end{array}$ & $\begin{array}{l}\text { Navarra (municipality of } \\
\text { Braga) }\end{array}$ & Un \\
\hline $\begin{array}{l}\text { Quinta of Crespos with three } \\
\text { couples to work the land ( } 4 \\
\text { caretakers) }\end{array}$ & $\begin{array}{l}\text { Crespos (municipality of } \\
\text { Braga) }\end{array}$ & $\begin{array}{l}\text { Third part available of } \\
\text { institutors' patrimony }\end{array}$ \\
\hline Quinta of Real & $\begin{array}{l}\text { São Jerónimo de Real } \\
\text { (municipality of Braga) }\end{array}$ & $\begin{array}{l}\text { Third part available of } \\
\text { institutors' patrimony }\end{array}$ \\
\hline Casal of Real & $\begin{array}{l}\text { São Jerónimo de Real } \\
\text { (municipality of Braga) }\end{array}$ & $\begin{array}{l}\text { Traded by the Casal of } \\
\text { Vinhal in Semelhe } \\
\text { (municipality of Braga) }\end{array}$ \\
\hline Casal of Proidelog & $\begin{array}{l}\text { São Jerónimo de Real } \\
\text { (municipality of Braga) }\end{array}$ & $\begin{array}{l}\text { Traded by Casal of Rego in } \\
\text { Navarra (municipality of } \\
\text { Braga) }\end{array}$ \\
\hline
\end{tabular}

\footnotetext{
${ }^{\text {aa }}$ The document does not specifically refer to this toponymic. It mentions that they are in front of the main door, on the right side, which coincides with Rua Pequena. These houses made a corner for the north half of Rua de Paimanta. See figure 2.

${ }^{\mathrm{b}}$ It has a closed door to the street and is connected to the big houses by some stone stairs inside.

${ }^{\mathrm{c}}$ See Note 1 regarding toponymal overlap between Rua de Santiago and Rua de Santa Maria.

${ }^{\mathrm{d}}$ Regarding the designation of Rua de Palhas.

${ }^{\mathrm{e}}$ With a small orchard to produce wine or fruit

${ }^{\mathrm{f}}$ Although the provenance of this property is not mentioned, I believe it is from the old bond, from which, incidentally, it takes its name.

$\mathrm{g}$ "That was of the hospital". ADB, Quinta de Real, Requerimento do Excelentíssimo Visconde do Amparo..., f. 4. It is not certain that this is a reference to the casal who supported, with their income, the Hospital od Santiago, because the said casal was exchanged for another one, in order to create two couples contiguous to the Quinta of Real.
} 


\begin{tabular}{lll} 
Casal of Gémeos (2 caretakers) & $\begin{array}{l}\text { Oliveira, next to Mosteiro de } \\
\text { Fonte Arcada (municipality of } \\
\text { the county of Lanhoso) }\end{array}$ & $\begin{array}{l}\text { Unknown } \\
\text { Estates }\end{array}$ \\
$\begin{array}{lll}\text { São Tiago de Francelos } \\
\text { (county of Prado) }^{\mathrm{i}}\end{array}$ & $\begin{array}{l}\text { Traded with Diogo Gomes } \\
\text { de Abreu for some houses in } \\
\text { Rua de Palhas } \\
\text { Beatriz (mother of Lopo de } \\
\text { Barros) }\end{array}$ \\
Rasal of Fremonde & Regalados $^{\mathrm{j}}$ & $\begin{array}{l}\text { Beatriz (mother of Lopo de } \\
\text { Barros) }\end{array}$ \\
\hline
\end{tabular}

Source: ADB, Quinta de Real, Requerimento do Excelentíssimo Visconde do Amparo..., 1862, n. . 36, ff. 2-

$4 \mathrm{v}$.

\footnotetext{
${ }^{\mathrm{h}}$ The monastery of Fonte Arcada is located in the county of Oliveira, which part of the current municipality of Póvoa de Lanhoso.

${ }^{\text {i }}$ Parish attached to that of Santa Maria de Prado. It is part of the current municipality of Vila Verde.

${ }^{\mathrm{j}}$ County extinct in 1855 and integrated in the current municipality of Vila Verde.

${ }^{\mathrm{k}}$ The morgado only mentions, in the description of the bonded properties, that Quinta of Ventosa and the Casal of Fremonde were given by D. Beatriz. Further on, in reference to the masses, it is clarified that the properties come from D. Beatriz Vaz. Valentim de Barros, father of the founder, donated, according to Domingos Affonso, the Ventosa farm and the Casal of Fremonde in Penela de D. João de Castro. Therefore, this D. Beatriz would be the mother of the founder.

1 "Land of Dom Simão of Castro, in the parish of Câmara de Cabaços". ADB, Quinta de Real, Requerimento do Excelentíssimo Visconde do Amparo..., f. 4v. I believe it is the municipality of Portela de Penela, which, due to the $19^{\text {th }}$ century liberal reform, was extinguished. Its parishes were integrated in the current municipalities of Ponte de Lima and Vila Verde. Azões and Portela das Cabras, in the Parish Memories of 1758, are identified as parishes in the municipalities of Albergaria de Penela and Portela de Penela.
} 


\section{[PG11]}

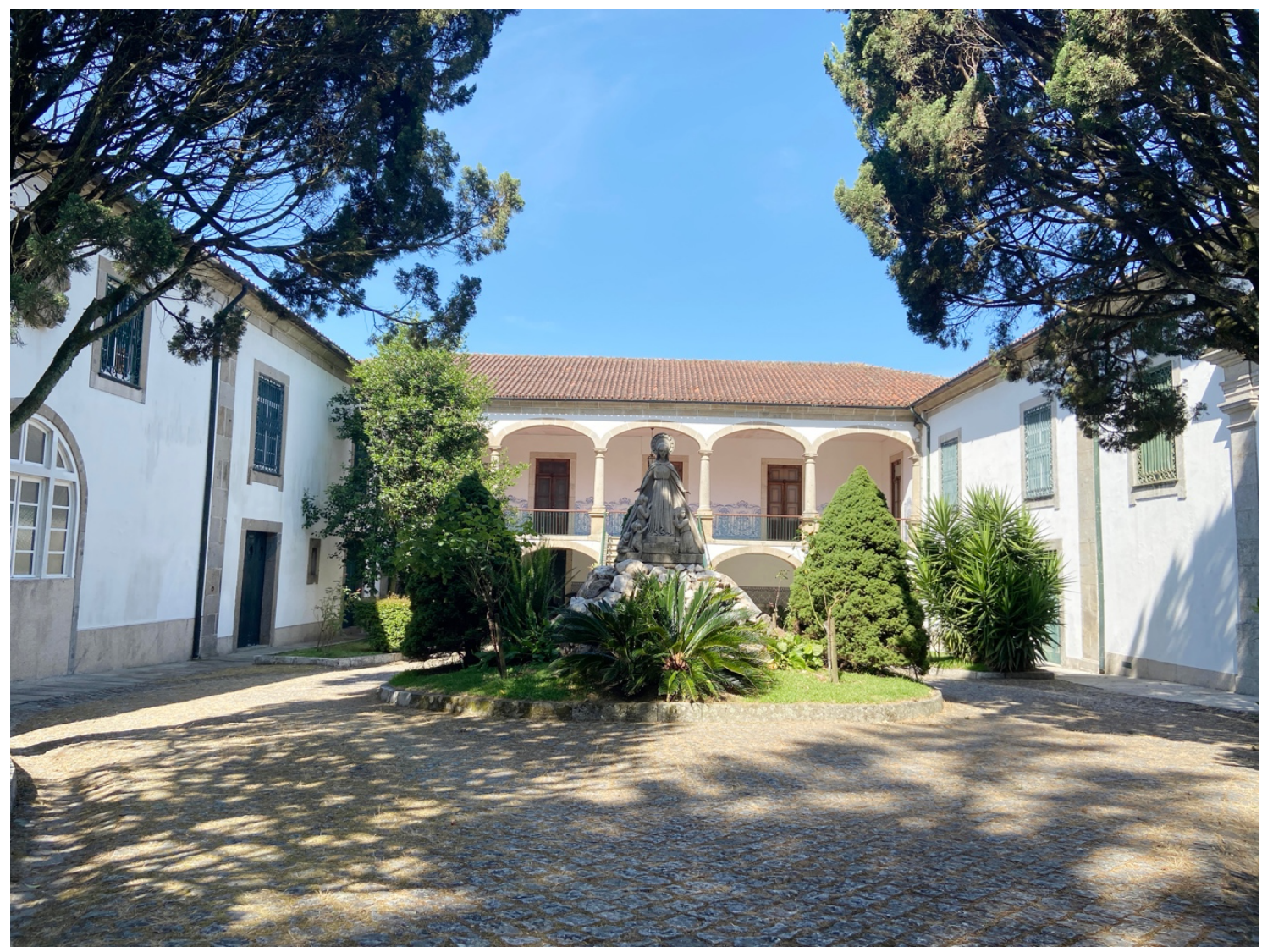

Figure 4. Quinta of Real, present time. Source: Photography of the author. Courtesy of Congregação Religiosa das Servas Franciscanas de Nossa Senhora das Graças.

Table 2. Mandatory Masses of Chapel of Nossa Senhora da Graça of the morgado of Real (1539)

Intention

Soul of Martim Martins de Barros

Soul of Lopo de Barros and Beatriz Weekly mass on Wednesdays

Bravo de Araújo

Soul of Diogo Bravo and Beatriz Vaz Weekly mass on Saturdays

Soul of Kings Afonso V of Portugal, Birthday mass on Dia de Reis (6 January)

João II of Portugal and Manuel I of and on the Octave of Christmas

Portugal

Source: ADB, Quinta de Real, Requerimento do Excelentíssimo Visconde do Amparo..., ff. 10v. e 14v. 

https:/www.tandfonline.com/doi/full/10.1080/20514530.2021.1988613

the royal family, both in the context of the entailed properties and in the system of representation of institutions of assistance and in chapels, must be understood as a proclamation of the public authority and wealth of the family ${ }^{94}$. The testimonies of witnesses of the morgado of Real's foundation attest to the position of the power and authority of the lineage in the present and in the future, for the duration of the body and the soul ${ }^{95}$.

Service to the crown of Portugal justified the reinforcement of the economic assets fundamental to living "like nobility". This had a "corpus", because it was lived in a space: the chapel. The mechanisms of ostentation and affirmation of the social and economic power of an individual or his lineage interpenetrated with the matters of salvation of the soul. Pious legacies were forms of the eternal reproduction of the memory of the founder and the heirs, as holders of all available resources of symbolic supremacy. The chapel was a place of remembrance of the power arising from antiquity and the power relations from which the bond had been formed. The experience of this memory took place in the public space, so the re-founders recommended to their successors certain rituals, namely [PG12] that they would listen to the weekly masses, cover the graves on All Souls' day and carefully choose the clergyman responsible for the religious service and the cleanliness of the chapel and its surrounding ${ }^{96}$. Land ownership, coats of arms (see Figure 5), use of the name and management of the memory all converged in the same purpose of representing the power arising from the family's seniority. 


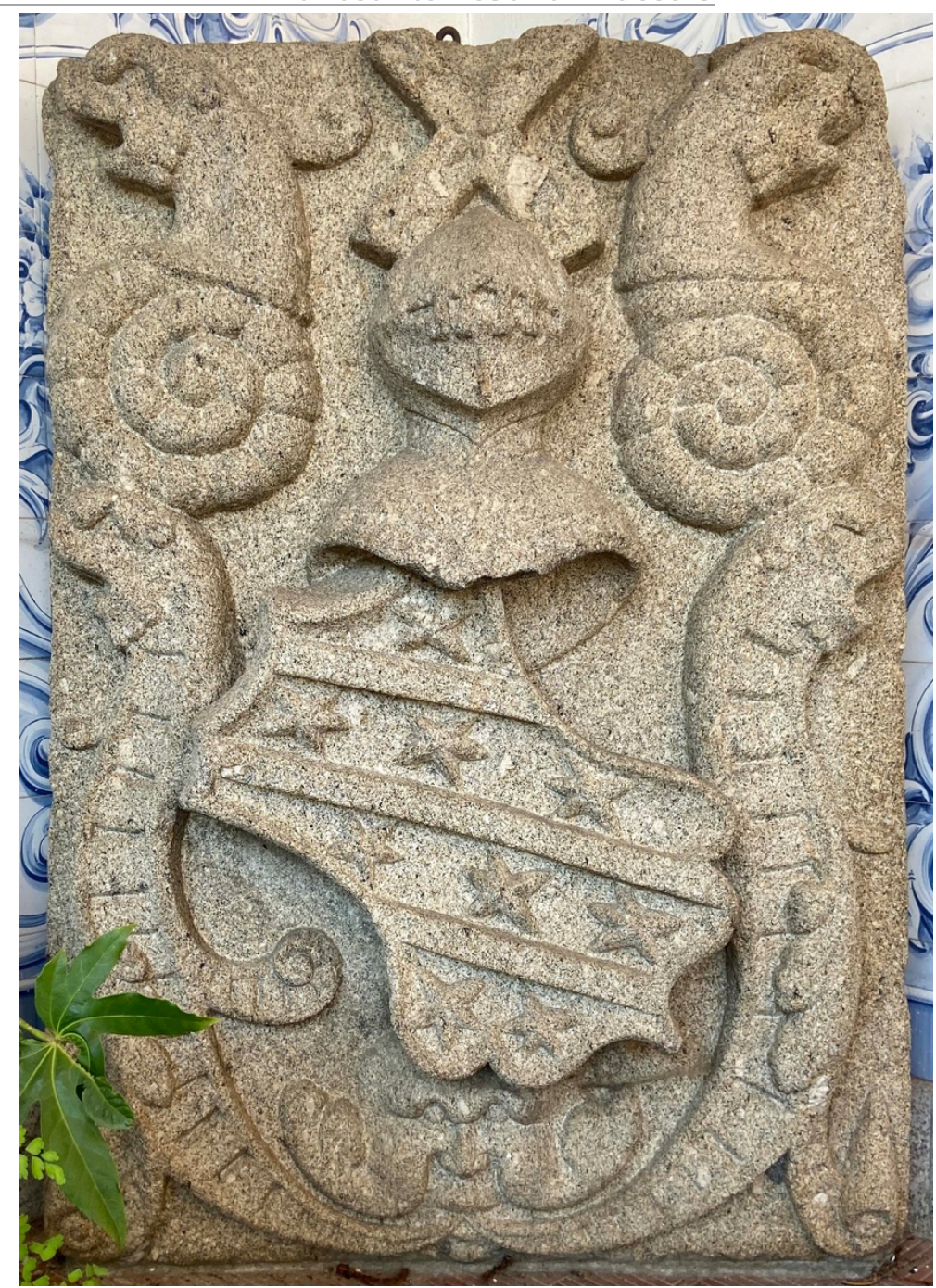

Figure 5. Barros Family Coat of Arms in Stone. Source: Photography of the author. Courtesy of Congregação Religiosa das Servas Franciscanas de Nossa Senhora das Graças

In 1503, when transferring the chapel of Nossa Senhora da Graça in the cloister of the Se Cathedral (see figure 6), Lopo de Barros imposed the family lineage, memory and pantheon in an important place in the "post-mortem" representation of the power of that time. In the cloisters was the chapel of São Tomás ${ }^{97}$, where the Portuguese count and countess $^{98}$ - D. Henrique (c.1096-112) and D. Teresa and archbishop D. Lourenço Vicente (p. 1374-1397) lay. By their side, in the chapel of Santa Bárbara, three daily masses were prayed for the soul of the Portuguese king D. Dinis (r. 1279-1325). D. Diogo de Sousa (p. 1505-1532), in 1513, had the chapel of Nossa Senhora da Piedade built in the same space, which received his tomb and where the brotherhood of Misericórdia originally functioned $^{99}$. D. Teresa de Sousa, sister of this prelate, [PG13] chose the chapel of Nossa Senhora da Paz, located in the same space, for her grave site ${ }^{100}$. The Barros, in 
addition to reconfiguring the family's material resources, restructured the representation of their nobility in this important sacred territory, which was much disputed by the highest dignitaries of the city of Braga at the time,. As can be seen in Figure 6, the Barros' chapel still stands today with the family's coat of arms conserved. The masses mentioned in Table 2 were said inside this temple during the Early Modern Age.

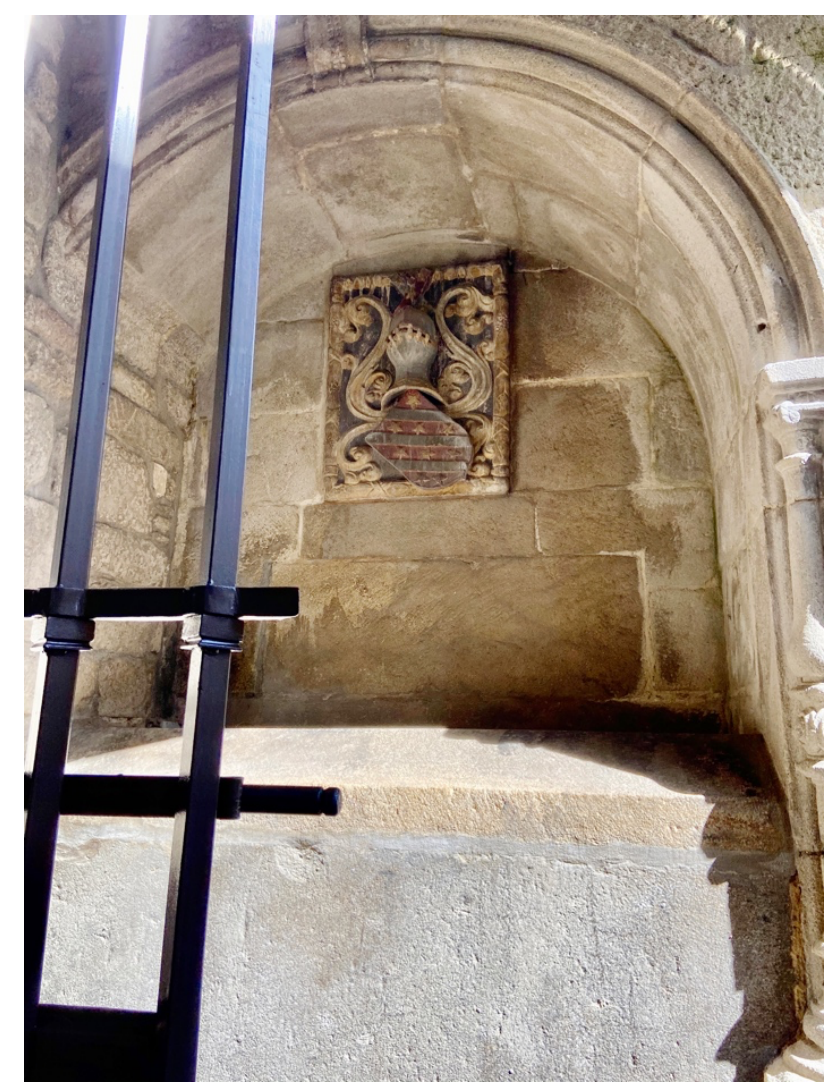

Figure 6. Chapel of Nossa Senhora das Graças, present time. Source: Photography of the author. Courtesy of Museum Treasury, Sé of Braga.

Hospital de Santiago was part of the old bond's basic obligations. During this period, aiding institutionalized assistance conferred prestige to the name of the benefactor and of his family ${ }^{101}$. Strict compliance with these obligations guaranteed descendants the material conditions to live like nobility, because "if what is mentioned in said chapel and masses each year are fulfilled and met, all the extra income that the morgado produces is for the heirs [of the institutors] to do with as it suits them"102. If the heirs did not comply with the established clauses, they would lose the management of the entailed patrimonial assets. Chapel and hospital, whilst assets of the soul, were not independent of support from the lineage; the name of the Barros family would continue to play a role in the fulfilment of the established pious expenses. 
This is an Accepted Manuscript of an article published by Taylor \& Francis in INTERNATIONAL JOURNAL OF REGIONAL AND LOCAL HISTORY on 07 of November of 2021 available online: https:/www.tandfonline.com/doi/full/10.1080/20514530.2021.1988613

[PG14] The family assumed the patronage and the administration of the hospital, ${ }^{103}$ because the holder of the bond was responsible for taking care of the integrity of the building, including re-tiling it; they also determined which women could live under its roof $^{104}$. The protectorate was entrusted to the 'judge' of the brotherhood of São Tiago who, each year, on the eve of the said saint's day of invocation (July 25), was responsible for overseeing the fulfilment of obligations. For this service, he would receive a monetary compensation of 100 reais. Should the brotherhood be extinguished, that responsibility would pass to the eldest town councilman ${ }^{105}$. Probably to protect again the eventuality of the family moving away from the city or not fulfilling the terms of their commitment, the institutors established surveillance functions for a brotherhood that operated in the parish church to which the hospital belonged and to the head of the old bond - see figure $2^{106}$. In the case of goods of the soul, jurisdictional protection belonged to the archbishops ${ }^{107}$.

\section{Conclusion}

Hospital de Santiago, which provided a home for poor women, operated on the ground floor of the houses that the "Morreira bond" had on Rua de São Tiago / Rua de Santa Maria and was part of a wider set of properties that headed the morgado established during the Late Middle Ages. Chapel, morgado and hospital articulated the affirmation of the family lineage in time and space, being physically present in the streets that surrounded the cathedral. In the 16th century, this bond was reinforced and extended by a descendant of the founder, D. Lopo de Barros, and his wife, D. Beatriz Bravo de Araújo, who formally instituted the "morgado of Real". In addition to strengthening the heritage of their ancestors, these successors increased their symbolic and patrimonial presence. The farm was also integrated, which would become the palatial residence of the family in the rural surroundings of the city of Braga.

The actualization of the Barros project is understandable because of its maintenance of important social structures: the belief that death does not discontinue human existence, the power of physical actions in interfering with the salvation of the soul and the active role of the poor in the remission of the sins of rich; the evidence that nobility came from a birth right, based on the antiquity and prestige of the ancestors, perceived by the maintenance of certain symbols, such as the name, morgado, the coats of arms, the manor, the chapels and the sponsorship of the hospital. Nobility and charity were tied up in the importance of giving and receiving. 
This is an Accepted Manuscript of an article published by Taylor \& Francis in INTERNATIONAL JOURNAL OF REGIONAL AND LOCAL HISTORY on 07 of November of 2021 available online: https:/www.tandfonline.com/doi/full/10.1080/20514530.2021.1988613

The old bond and the re-founding bond constituted the pillars on which the Barros lineage and representation were materially and culturally based. Family power, the guarantee of legitimate succession and maintenance of the social structures underlying the morgadio, the chapels and charity as an "ethos" of aid, allow an understanding of the hospital's permanence in Braga's assistance network. Only the normative force of liberalism, which outlawed the properties of blood and souls, ended this project of the medieval founder.

\section{[PG22]}

\section{Acknowledgements}

Our supervisor, Lecturer Maria Marta Lobo de Araújo, $\mathrm{PhD}$, for her reading, suggestions and reviews of this text. To the Director and staff of Arquivo Distrital de Braga, specially to Sandra Meneses and Luís Araújo, for making the documentation in archive available. To the Director of Colégio de Nossa Senhora das Graças and of Congregação Religiosa das Servas Franciscanas de Nossa Senhora das Graças de Braga, Sister Augusta da Conceição Mendes, for the availability and kindness evidenced in the guided tour of the old manor house of the Barros Family, in Real, current office of the institutions she presides; an acknowledgement also extended to Susana Vaz and Epifânia Oliveira. To the staff of Arquivo Municipal de Braga, for the support in the unsuccessful researches. To the Director of Tesouro-Museu da Sé de Braga, Canon João Paulo Abreu, and to Fernanda Barbosa, for allowing the photographic capture of Capela de Nossa Senhora da Graça.

\section{Disclosure Statement}

No potential conflict of interest was reported by the author(s).

\section{Funding}

This work was supported by the Foundation for Science and Technology (FCT) under Grant 2020.04746.BD.

[PG23]

\section{Note on contributor}

Luís Gonçalves Ferreira holds a degree in History (2017) and a master's degree in History (2019) from the University of Minho. He is a researcher of Lab2PT (UMinho). His 
This is an Accepted Manuscript of an article published by Taylor \& Francis in INTERNATIONAL JOURNAL OF REGIONAL AND LOCAL HISTORY on 07 of November of 2021 available online: https:/www.tandfonline.com/doi/full/10.1080/20514530.2021.1988613

master's thesis was published in a book, published by Húmus in March 2020, entitled "Vestidos de caridade: assistência, pobreza e indumentária na Idade Moderna. O caso da Misericórdia de Braga". He is interested in the fields of poor-relief, body history, gender, sexuality and mentalities. The results of his studies have been published in chapters of books or scientific articles and discussed in several scientific meetings in Portugal and abroad. At the moment, he is doing his PhD in Early Modern History at the University of Minho (Braga, Foundation Portugal) intitled "Poor, sick and ragged? Clothing of the poor in the urban assistance context of Porto and Lisboa (17th and 18th centuries)" with a $\mathrm{PhD}$ Research Scholarship by Foundation for Science and Technology (FCT).

${ }^{1}$ In accordance with the index of the Chapter and the document of establishment of the morgado, of 1539 , the street of the hospital came to be called "Rua de Santiago". During the Middle Ages, it was called Rua da Erva and Rua da Judiaria Velha because it was located next to the door of São Tiago. Later, the street changed its name to Rua de Santa Maria or Rua do Poço. It should be noted that, in 1791, the Church of Cividade underwent architectural changes that translocated the facade from east to west, a position in which it currently finds itself. Maria do Carmo Franco Ribeiro, «Braga entre a época romana e a Idade Moderna. Uma metodologia de análise para a leitura da evolução da paisagem urbana» ( $\mathrm{PhD}$ diss., Braga, Universidade do Minho, 2008), 411-536.

${ }^{2}$ District Archives of Braga (ADB); Chapter of Sé Cathedral, Braga, Livro de Prazos do Cabido, n. ${ }^{\circ} 10$, ff. $248 v$. e 250.

${ }^{3}$ ADB, Parish of Cividade, Livro de Registo de Óbitos, 1772-1837, n. ${ }^{\circ} 79$, f. 171v.

${ }^{4}$ The quotation is from the entry of the town of Braga in the incomplete geographical dictionary written by Luís Cardoso, published in 1747.

${ }^{5}$ Bernardino José de Senna Freitas, Memorias de Braga contendo muito interessantes escriptos extrahidos e recopilados de diferentes archivos assim de obras raras como de manuscriptos ainda inéditos e descripção de pedras inscripcionaes, vol. 1 (Braga: Imprensa Catholica, 1890), 116 and 155.

${ }^{6}$ This research derives from my Master's dissertation research about the practices of almsgiving to poor people by Santa Casa da Misericórdia of Braga, I was confronted with countless records of alms to dead people in an institution named Hospital de Santiago, located in Braga.

${ }^{7}$ This methodology finds parallel in studies developed by Archaeology and Urban History. See, for example, Ribeiro, «Braga entre a época romana e a Idade Moderna. Uma metodologia de análise para a leitura da evolução da paisagem urbana»,181-199; Maria do Carmo Franco 
Ribeiro and Maria Manuela Martins, «Contributo para o estudo do abastecimento de água à cidade de Braga na Idade Moderna: o livro da Cidade de Braga (1737)», in Caminhos da Água: paisagens e usos na longa duração, ed. Manuela Martins, Isabel Vaz Freitas and Maria Isabel Del Val Valdivieso [Braga: Centre for Transdisciplinary Research, «Cultura, Espaço e Memória» (CITCEM), 2012], 179-221.

${ }^{8}$ This document is transcribed in a memoir of the old bonds of Braga of the Judge of Residuos, dated 1587. That magistracy of the government of Mitra Arquiepiscopal of Braga was occupied by one of the judges of the Relação Eclesiástica (court of appeal), who was responsible for the inspection of the fulfilment of the last wishes of the deceased; it had secular and ecclesiastical jurisdiction in the city. About the competences in this magistrature Ana Sandra Meneses, «Arquivo do Arcebispo Primaz de Braga», Fórum, n. 40 (2006): 135.

${ }^{9}$ In the context of this text, the use of the terms "medieval" or "Middle Ages" correspond to the Late Middle Ages (11th-15th centuries).

${ }^{10}$ Alberto Feio, Coisas Memoráveis de Braga e Outros Textos (Braga: University of Minho and the Public Library of Braga, 1984), 84.

${ }^{11}$ José Marques, «A assistência no Norte de Portugal nos finais da Idade Média», História Revista da FLUP 6 (1989): 49.

${ }^{12}$ Although, in the medieval period, the terms hospital and "albergaria" (inn) were synonyms, José Marques and Maria do Carmo Ribeiro mention them as separate institutions. Cf. Maria Helena Cruz Coelho, «A ação dos particulares para com a pobreza nos séculos XI e XII», in A pobreza e a assistência aos pobres na Península Ibérica durante a Idade Média. Actas das 1.as jornadas luso-espanholas de História Medieval, vol. I (Lisbon: Instituto de Alta Cultura - Centro de Estudos Históricos, 1973), 245; Maria do Carmo Ribeiro, «A implantação das instituições de assistência na paisagem urbana medieval: reflexões sobre os processos de urbanização das cidades de Braga e Guimarães (Norte de Portugal)», in Civitas bendita : encrucijada de las relaciones sociales y de poder en la ciudad medieval, ed. Gregoria Cavero Domínguez (Leão: University of León and Área de Publicaciones, 2016), 67-72.

${ }^{13}$ José Marques, «O culto de São Tiago no Norte de Portugal», Lusitana Sacra, 2. ${ }^{\text {a }}$ série, n. 4 (1992): 130.

${ }^{14}$ José Marques, «O Minho na Baixa Idade Média», in Minho. Traços de Identidade (Braga: Universidade do Minho, 2009), 356.

${ }^{15}$ Ribeiro, «A implantação das instituições de assistência na paisagem urbana medieval: reflexões sobre os processos de urbanização das cidades de Braga e Guimarães (Norte de Portugal)», $67-72$. 
${ }^{16}$ Leonardo Manuel Cabral da Silva, «Arquitetura das estruturas de assistência no Norte de Portugal (séculos XII a XVI)» (Master's diss., Faculty of Literature, University of Porto, 2017), 124-25.

${ }^{17}$ Maria Marta Lobo de Araújo, «A oferta assistencial na Braga Setecentista», in El mundo urbano en el siglo de la Ilustración: actas da Reunión Cientifica de la Fundación Española de Historia Moderna, 10, Santiago de Compostela, 2009., ed. Ofélia Rey Castelao e Roberto López J., vol. 2 (Santiago de Compostela: Dirección Xeral de Turismo, 2009), 245-56.

${ }^{18}$ Laurinda Abreu, O poder e os pobres: as dinâmicas políticas e sociais da pobreza e da assistência em Portugal (séculos XVI-XVIII) (Lisbon: Gradiva, 2014), 254.

${ }^{19}$ Institutions called "hospitalillos" or "hospitalicios" were usual in all of urban and rural Spain during the Early Modern age. Some of them were founded in the medieval period as is the case in this study. See, for example, the cases of Santiago de Compostela (Galicia), Castile and León, Álava (Basque Country) and Jaén (Andalusia): Baudillo Barreiro Mallón e Ofelia Rey Castelao, Pobres, Peregrinos y Enfermos: La red asistencial gallega en el Antiguo Régimen (Santiago de Compostela: Consorcio de Santiago e Nigra Arte, s.d.), 60-67; Manuel Ferreiro Ardións e Juan Lezaun, «La asistencia hospitalaria en Álava durante la Edad Moderna», Sancho el Sabio, n. 38 (2015): 229; Alfredo Martín García, «Hospitales y refugios: la red asistencial leonesa durante el siglo XVIII», in Marginalidade. Pobreza e respostas sociais na Península Ibéria (séculos XVI-XX), ed. Maria Marta Lobo de Araújo e Alexandra Esteves (Braga: CITCEM, 2011), 193-98; José María Díaz Herández, «El antiguo "Hospitalico" de Jesús, María y José de la ciudad de Jaén: Una institución benéfica, por y para mujeres.», in I Congreso Virtual sobre historia de las mujeres (First virtual Congress about the history of women, Jaén: Asociación de Amigos del Archivo Histórico Diocesano de Jaén, 2009), 1-9.

${ }^{20}$ Paulo Drumond Braga, «A crise dos estabelecimentos de assistência aos pobres nos finais da Idade Média», Revista Portuguesa de História, n. XXVI (1991): 175-90.

${ }^{21}$ Sandra Cavallo, Charity and Power in Early Modern Italy: Benefactors and their Motives in Turim 1547-1789 (New York: Cambridge University Press, 1995), 100.

${ }^{22}$ Abreu, O poder e os pobres: as dinâmicas politicas e sociais da pobreza e da assistência em Portugal (séculos XVI-XVIII), 261.

${ }^{23}$ Maria de Lurdes Rosa, «A religião do século: vivências e devoções dos leigos», in História Religiosa de Portugal: Formação e Limites da Cristandade, ed. Carlos Moreira Azevedo, vol. 1 (Lisbon: Círculo de Leitores, 2000), 461.

${ }^{24}$ Ângela Barreto Xavier e António Manuel Hespanha, «As redes clientelares», in História de Portugal: O Antigo Regime (1620-1807), ed. José Mattoso, vol. 4 (Lisbon: Editorial Estampa, 1998), 339-49. 
${ }^{25}$ Isabel dos Guimarães Sá, «Pobreza», in Dicionário de História Religiosa de Portugal, ed. Carlos Moreira Azevedo (Lisbon: Círculo de Leitores e Centro de Estudos de História Religiosa da UCP, 2001).

${ }^{26}$ According to Maria de Lurdes Rosa, this relationship between the morgadio, assumed in the will of its institutor was profound and the importance of memorizing the past through the repetition in the future of public acts based on a patrimonial basis. Cf. Maria de Lurdes Rosa, O morgadio em Portugal (sécs. XIV-XV): modelos e práticas de comportamento linhagístico (Lisbon: Editorial Estampa, 1995), 50-54.

${ }^{27}$ The ecclesiastical reserve precedes the foundation of the Kingdom of Portugal and was donated to the archbishop of Braga by Count D. Henrique, in 1112, and corresponded, roughly, to the city of Braga. This lordship was abolished in 1790 through the law on the abolition of grantees. The suffragan territory of the archdiocese of Braga, was very extensive and has been reduced, by the creation of other dioceses, such as Miranda do Douro (1545), Vila Real (1922) and Viana do Castelo (1987).

28 “Carta de Lei” of May 20, 1863 in Colleção Oficial da Legislação Portuguesa redigida por José Maximo de Castro Vasconcelos 1864, 200-201. The document that allowed an identification of the bond for the institution of Morgado of Real, dated 1862 (see note 16), must have been drawn up in the course of the law preceding the extinction of the bonds, dated 1860, which determined the mandatory registration of all the morgados and chapels. The titleholder of Barros house, in the second half of the 19th century, was the 1st Viscount of Amparo, Rodrigo Barba Alardo de Lencastre e Barros, petitioner of this document.

${ }^{29}$ The chapel and morgado of the Barros family did not have independent bonds between them, because the heritage that was associated with them served to carry out the suffrages of the soul and to support the nobility of the lineage.; this is why the term "morgado-chapel" is used. Throughout the text, the word "chapel (EN) / capela (PT)" is used in its double meaning: as a locale edified with an altar where masses were held; and as a juridical bond that configured an inalienable certain inheritance dedicated to the realization of perpetual suffrages. Guilherme Alves Moreira, Instituições do Direito Civil Português, vol. III, IV vols. (Coimbra: Imprensa da Universidade, 1907), http://www.governodosoutros.ics.ul.pt.

${ }^{30}$ Domingos de Araújo Affonso, «Da verdadeira origem de algumas famílias ilustres de Braga e seu termo. XVIII Barros de São Jerónimo de Real», Bracara Augusta XXIV, n. 57-58 (6970) (1970): 124.

${ }^{31}$ Felgueiras Gaio, Nobiliário de Famílias de Portugal, ed. Agostinho de Azevedo Meirelles e Domingos de Araújo Affonso, vol. Tomo VI (Braga: Oficinas Gráficas da «Pax», 1938), 134.

32 Parochial Memoirs of Sé (1758) mentions that Morreira's bond had instituted Archdeacon of Braga Dom Martim Martins de Barros during the time of Archbishop Dom Estêvão Soares 
da Silva (Arquivo Nacional Torre do Tombo - Lisbon, Memórias Paroquiais, Paróquia de Braga (Sé), 1758, n. ${ }^{\circ}$ 57, pg. 1117). This is the only documentary evidence with an approximate reference to the foundation of the bond; however, it was written many centuries after the foundation, which does not allow for reliable assertation. Handwritten or printed genealogical works are contradictory in this respect. On the other hand, Alberto Feio (1992: 130) identified an Albergaria Nova da Cividade, which was a hospital for women that would later be called Hospital das Velhas, which, in 1324, received a legacy. José Marques (1992: 130) wrote that the Albergaria de São Tiago was already operational in 1249. No Archdeacon Martim Martins de Barros appears in the list of canons from Braga between 1245 and 1347 (AMSA Rodrigues et al. 2005: 125-139), which just refutes the hypothesis that the founder was a member of the Braga chapter during that period. Cf. Feio, Coisas Memoráveis de Braga e Outros Textos, 130; Marques, «O culto de São Tiago no Norte de Portugal», 130; Ana Maria S. A. Rodrigues et al., Os capitulares bracarenses (1245-1374): notícias biográficas (Lisbon: Centro de Estudos de História Religiosa/Universidade Católica Portuguesa, 2005), 125-39.

${ }^{33}$ Affonso, «Da verdadeira origem de algumas famílias ilustres de Braga e seu termo. XVIII Barros de São Jerónimo de Real», 124; Gaio, Nobiliário de Famílias de Portugal, Tomo VI:158.

${ }^{34}$ As evidenced by a certificate dated October 28, 1862 notarised by the notary Francisco José Peixoto Vieira. This public notary handed over a document with a letter from the 17th century, which is presented in the annex. These two documents are similar in content to each other, which is the copy closest to the date of the original bond and which, as mentioned, is found in one of the books of the Judge of Residues of Mitra, archdiocesan council of Braga. The documents are identical, but the 19th century certificate has some toponymical inaccuracies. After comparing the three manuscripts, corrections were made according to the oldest copy (ADB, Quinta de Real, Requerimento do Excelentissimo Visconde do Amparo, residente na sua Quinta do Amparo, do concelho de Leiria, de certidão e teor da instituição do Morgado de Lopo de Barros que se acha no livro que servia no ano de 1670, folha 26, do extinto Juízo dos Resíduos e respetiva certidão, 1862, n. ${ }^{\circ} 36$ ).

${ }^{35}$ At an unknown time, the houses of the hospital gained another floor. It is certain that, in the 18th century, the priest Luís Cardoso (1747: 261) mentions that the old women lived in the lower part of the houses. A floor must have been added after the institution of Morgado of Real; on the map of Braun (1594), these buildings already appear with two floors. See Luís Cardoso, Diccionario geografico, ou noticia historica de todas as cidades, villas, lugares, e aldeas, rios, ribeiras, e serras dos Reynos de Portugal, e Algarve, com todas as cousas raras, que nelles se encontraõ, assim antigas, como modernas / que escreve, e offerece ao 
muito alto... Rey D. João V nosso senhor o P. Luiz Cardoso, da Congregaçaõ do Oratorio de Lisboa (Lisbon: Regia Officina Sylviana da Academia Real, 1747), 261.

${ }^{36}$ See footnote 1 .

${ }^{37}$ Bluteau (1713a, 2: 237) mentions that a censo is "an income from some real estate that is paid to the landlord". According to Moreira (1907, III: 103-104), unlike leaseholders, where a domain is received for a rent delivered to the landlord of the property and who retain their right of property, "the rent payer is, fully, the owner of the thing received from the censo". The recipient of the censo may dispose of it against the will and without the knowledge of the landlord, and it is therefore not surprising that a property could be bonded. In this case, the censo was paid to Morgado of Real, as an entity with its own legal personality.

${ }^{38}$ ADB, Índice dos Prazos..., f. 248.

${ }^{39}$ ADB, Quinta de Real, Requerimento do Excelentissimo Visconde do Amparo..., ff. 2 e 2v.

${ }^{40}$ The map, which is part of a private collection, was published in the Forum journal in the $90 \mathrm{~s}$ in the past century. Henrique Barreto Nunes, «Uma imagem inédita de Braga no século XVII», FORUM, n. 15/16 (1994): 23.

${ }^{41}$ Mappa da Cidade de Braga Primaz, 1756-57, de André Ribeiro Soares da Silva. Braga: Município de Braga, 2015.

${ }^{42}$ As in Planta Tipográfica da Cidade de Braga of Francisque Goullard (1883/84), published by Miguel Sopas Bandeira Miguel Sopas Bandeira, ed., Planta Tipográfica da Cidade de Braga de Francisque Goullard (1883/84) (Braga: Município de Braga, 2015), 59.

${ }^{43}$ Miguel Sopas Bandeira, O espapo urbano de Braga em meados do século XVIII (Porto: Edições Afrontamento, 2000), 114-15.

${ }^{44}$ See the case studies of Coimbra, Porto and Lisbon «A assistência em Coimbra na Idade Média: dimensão urbana, religiosa e socioeconómica (séculos XII a XIV)» (PhD diss., Coimbra, Universidade de Coimbra, 2019), 403-9; Liliana Paula Teixeira Ribeiro, «A arquitetura neopalladiana portuense: o Hospital de Santo António (1679-1832)» (PhD diss., Porto, Faculdade de Letras da Universidade do Porto, 2012), 74-82; Paulo Lopes, «A assistência hospitalar medieval anterior à instituição do Hospital Real de Todos os Santos» (Dissertação de Mestrado, Lisbon, Faculdade de Ciências Sociais e Humanas, Universidade Nova de Lisboa, 2015), 16-61.

${ }^{45}$ The houses were single storey in 1539 confirmed by Luís Cardoso in the 18th century. See note 18.

${ }^{46}$ House number 17 in the rent contract of the Chapter's houses, which faces the hospital in the north, had a covered floor area of $100 \mathrm{~m}^{2}: 6$ varas $(7 \mathrm{~m})$, East to West by 13 varas $(14 \mathrm{~m})$, North to South - and a small backyard with an area of $71.5 \mathrm{~m}^{2}$ (5 varas by 13 varas). In the 18th century, the backyard had already been transformed into a square onto which there was a balcony. This property, in the 18th century, had a well, a wine cellar, six shops, three 
rooms with bedrooms and a kitchen. The elevation of the building number 17 is smaller than the one corresponding to Hospital de Santiago, which infers its floor area was larger. Cf. ADB, Cabido da Sé de Braga, Livro de Prazos do Cabido, n. ${ }^{\circ}$ 97, ff. 22 a 28.

${ }^{47}$ In medieval Braga, $60 \%$ of the 363 houses in the "core area" were owned by the Chapter. In certain streets, namely Rua de Santa Maria / Poço, Rua Pequena, Rua de Maximinos, Rua de Santo António, Rua do Paimanta and the lane between Poço and Gualdim Pais, the institution owned almost all the houses. Bandeira, O espapo urbano de Braga em meados do século XVIII, 115.

${ }^{48}$ The dominant power of a secondary nobility - infanções - historically derived from the exercise of powers delegated by the first nobility - the count's. Between the beginning of the 11th century and the end of the 12th century, the power of the infanções became independent from the county nobility and they began to exercise dominion over the land in an autonomous way. The authority of the infanções were transmitted by blood, which, with weapons and power of command, was the basis of their condition. See José Mattoso, Naquele Tempo: Ensaios de História Medieval (Lisbon: Temas e Debates/Círculo de Leitores, 2009), 290-95.

${ }^{49}$ Bernardo Vasconcelos e Sousa e José Augusto de Sotto Mayor Pizarro, «A família. Estruturas de parentesco e casamento», in História da Vida Privada em Portugal: a Idade Média, ed. José Mattoso, vol. 1 (Lisbon: Temas e Debates/Círculo de Leitores, 2011), 134-40.

${ }^{50}$ During the first centuries of the Late Middle Ages, the cognatic and agnatical succession systems coexisted. See Bernardo Vasconcelos e Sousa, «Linhagem e Identidade Social na Nobreza Medieval Portuguesa (séculos XIII-XIV)», Hispania. Revista Española de Historia LXVII, n. 227 (2017): 889-98.

${ }^{51}$ The contract of the morgado of Real stated the following: "The morgado [old] was always and is the property of the eldest male child until the death of the last successor, without being able to denounce or alienate. The successor, in this said morgado, will dictate the masses prayed. (...) Give ownership to Diogo de Barros, firstborn and first successor of said morgado and associated and incorporated assets, (...) wish and order that all said assets are to take care of the firstborn eldest son descendant of Lopo de Barros and his wife as consecrated in the old succession". ADB, Quinta de Real, Requerimento do Excelentíssimo Visconde do Amparo..., ff. 4v. and 7v.

52 Rosa, O morgadio em Portugal (sécs. XIV-XV): modelos e práticas de comportamento linhagístico, 102.

${ }^{53}$ Rosa, «A religião do século: vivências e devoções dos leigos», 461.

${ }^{54}$ On the triumph of Purgatory and its impact on scholasticism and the mendicant orders see Jacques Le Goff, O nascimento do Purgatório, trad. Maria Fernanda Gonçalves de Azevedo (Lisbon: Editorial Estampa, 1995), 283-324. 
${ }^{55}$ André Vauchez, A espiritualidade na Idade Média Ocidental (séculos VIII a XIII), trad. Teresa Antunes Cardoso (Lisbon: Editorial Estampa, 1995), 156-75.

${ }^{56}$ José Mattoso, «O corpo, a saúde e a doença», in História da Vida Privada em Portugal: a Idade

Média, ed. José Mattoso, vol. 1 (Lisbon: Temas e Debates/Círculo de Leitores, 2011), 367.

${ }^{57}$ Marques, «O culto de São Tiago no Norte de Portugal».

58 On the values of devotion to Saint James from his medieval iconography see Begoña Farré

Torras, «Do apóstolo ao peregrino: a iconografia de São Tiago na escultura devocional medieval em Portugal», Medievalista online, n. 12 (2012): 28-31.

59 José Mattoso, «O Culto dos Mortos na Península Ibérica (séculos VII a XI)», Lusitana Sacra, n. 4 (1992): 26.

${ }^{60}$ Porto connected to Tui via three routes: the route that passed through São Pedro de Rates, Barcelos and Ponte de Lima; another, which passed through Guimarães and was connected to Ponte de Lima by Braga; another that connected Porto to Braga and from there to Ponte de Lima. The Hospital de Santiago was on the road that reached the southern door of the city, facing the Guimarães route. Humberto Baquero Moreno, «Vias portuguesas de peregrinação a Santiago de Compostela na Idade Média», Revista da Faculdade de Letras HISTÓRIA 3, n. 7 (1986): 77-89.

${ }^{61}$ José Marques, «Os santos dos caminhos portugueses», Revista da Faculdade de Letras HISTÓRIA 7, n. III (2006): 249-54.

${ }^{62}$ Despite being disregarded by philosophers, the physical dimension of the human being was a platform of connection with the divine. Mattoso, «O corpo, a saúde e a doença», 358-64.

${ }^{63}$ The individualization of religion and the conquest of the deeper personal experiences of the lay people, through recollection and reflection, is performed through the awareness of the presence of God in human beings and in societies. This requalification of the value of the human being transformed his relationship with God, essentially by the sacramental value of penance. From the 11th century onwards, confession, for being such a humiliating and painful act, acquires atoning value and an essential gesture for the salvation of punishment. Vauchez, A espiritualidade na Idade Média Ocidental (séculos VIII a XIII), 169-73.

${ }^{64}$ This deepening of self-awareness and of individualism due to the practices of penance and, notably of confession, was also emphasized for the early modern period. Francisco Bettencourt, «Penitência», in Dicionário de História Religiosa de Portugal, ed. Carlos Moreira Azevedo (Lisbon: Círculo de Leitores e Centro de Estudos de História Religiosa da UCP, 2001), 428.

${ }^{65}$ Philippe Ariès, $O$ homem perante a morte I, trad. Ana Rabaça, vol. 1 (Mem Martins: Publicações Europa-América, 1988), 117.

${ }^{66}$ José Ángel García de Cortazar e José Angel Sesma Muñoz, Manual de História Medieval (Madrid: Alianza Editorial, 2008), 234-46. 
${ }^{67}$ Marques, «A assistência no Norte de Portugal nos finais da Idade Média», 17 e 35-37.

${ }^{68}$ Lisbeth Rodrigues, «Os hospitais portugueses no Renascimento (1480-1580): o caso de Nossa Senhora do Pópulo das Caldas da Rainha» (PhD diss., Braga, Universidade do Minho, 2013), 21-22.

${ }^{69}$ On the difference between charity, mercy, beneficence and philanthropya see Maria Antónia Lopes, Pobreza, assistência e controlo social em Coimbra (1750-1850), vol. 1 (Viseu: Palimage Editores, 2000), 62-68.

${ }^{70}$ Founded in 1496, these brotherhoods of "immediate" royal protection saw their economic statute reinforced by the canons of post-Tridentine church. Laurinda Abreu, «Misericórdias: patrimonialização e controlo régio (século XVI-XVII)», Ler História, n. 44 (2003): 5-24.

${ }^{71}$ Isabel dos Guimarães Sá, Quando o rico se faz pobre: as Misericórdias, caridade e poder no império português (1500-1800) (Lisbon: Comissão Nacional para as Comemorações dos Descobrimentos Portugueses, 1997), 25-34.

${ }^{72}$ Braga, «A crise dos estabelecimentos de assistência aos pobres nos finais da Idade Média», 175.

${ }^{73}$ These innovations have been studied by Laurinda Abreu. In her studies, the author highlighted the monarchy's concerns about legally defining the deserving poor, the processes of incorporating several small hospitals into larger institutions, the organization and regulation of health professions, concerns about epidemics, the creation of Misericórdias and the integration of local power and the Church in this field. Abreu, O poder e os pobres: as dinâmicas políticas e sociais da pobreza e da assistência em Portugal (séculos XVI-XVIII), $19-78$.

${ }^{74}$ Sá, «Pobreza», 456; Xavier e Hespanha, «As redes clientelares», 344.

${ }^{75}$ Maria Marta Lobo de Araújo, «As Misericórdias e a salvação da alma: as opções dos ricos e os serviços dos pobres em busca do Paraíso (séculos XVI-XVIII)», in Problematizar a História - estudos de História Moderna em homenagem a M. ${ }^{a}$ do Rosário Themudo Barbosa (Lisbon: Caleidoscópio, 2007), 383-402.

${ }^{76}$ Maria Angela V. da Rocha Beirante, Territórios do sagrado: crenças e comportamentos na Idade Média em Portugal (Lisbon: Edições Colibri, 2011), 31. Our translation.

${ }^{77}$ Ângela Barreto Xavier, «Amores e desamores pelos pobres: imagens, afectos e atitudes (séculos XVI-XVII)», Lusitana Sacra, 2. , , n. 11 (1999): 59-85.

${ }^{78}$ The hospitals of the Chapter, D. Martinho, Maximinos, Nova da Cividade, São João do Souto, Rocamador, "Rocidevallis", Rua Nova, São Bartolomeu, São Marcos, Santiago, Santos do Paraíso and Velhas (Silva, «Arquitetura das estruturas de assistência no Norte de Portugal (séculos XII a XVI)», 48-49. There is great difficulty in settling the medieval institutions of Braga. Many of the names mentioned in the study of Leonardo Cabral da Silva show up 
between the brotherhoods that José Marques says were active in the Late Middle Ages in Braga.

${ }^{79}$ In the letter of institution of the Hospital de São Marcos, D. Diogo de Sousa mentions that the leper hospital was, for a long time, without sick people, and that Hospital da Rua Nova was very impoverished and that it was the only one in the city. D. Diogo de Sousa referred to the hospital in the modern sense of the term, that is, an institution with an associated clinical staff that provided bodily care. The document is published in Portugaliae Monumenta Misericordiarum Isabel dos Guimarães Sá and José Pedro Paiva, eds., Portugaliae Monumenta Misericordiarum. A Fundação das Misericórdias: o Reinado de D. Manuel I (Lisbon: União das Misericórdias Portuguesas, 2004), 40-46.

${ }^{80}$ Maria Marta Lobo de Araújo, «Sarar as feridas da alma no hospital da Misericórdia de Braga: a assistência espiritual aos enfermos no hospital de São Marcos (séculos XVI-XVIII)», in Santa Casa da Misericórdia de Porto Alegre. Histórias Reveladas VI (Porto Alegre: Santa Casa da Misericórdia de Porto Alegre, 2019), 149.

${ }^{81}$ Sousa, «Linhagem e Identidade Social na Nobreza Medieval Portuguesa (séculos XIII-XIV)», 896-99; Nuno Gonçalo Monteiro, «O “Ethos” Nobiliárquico no final do Antigo Regime: poder simbólico, império e imaginário social», Almanack Braziliense, n. 2 (2005): 6, https://doi.org/10.11606/issn.1808-8139.v0i2p4-20.

${ }^{82}$ Rosa, «A religião do século: vivências e devoções dos leigos», 480-83.

${ }^{83}$ Having the economic capacity to live in the manner of the nobility was, in the Early Modern Age, structural to the attainment of the prerogatives of its categorization. In a society based on a strong social hierarchy, the visualization of powers and the material perception of the hierarchy were a sine qua non condition for the existence of de facto power. As pointed out by Nuno Gonçalo Monteiro (2005: 17), the peninsular morgadio imposed a noble behaviour, namely, a strict social discipline of the family nucleus, subject to the will of the holder; alongside the coat of arms and other pictographic elements of the power of nobility and the model of obligatory reproduction, essential to the noble archetype. See Nuno Gonçalo Monteiro, «O "Ethos” Nobiliárquico no final do Antigo Regime: poder simbólico, império e imaginário social», 17.(2005: 17).

${ }^{84}$ Abreu, O poder e os pobres: as dinâmicas políticas e sociais da pobreza e da assistência em Portugal (séculos XVI-XVIII), 42.

${ }^{85}$ Nuno Gonçalo Monteiro, Elites e poder: entre o antigo regime e o liberalismo, 2. ${ }^{\text {a }}$ (Lisbon: ICS, 2007), 93-103.

${ }^{86}$ This what the contract refers to when the institutors declare that they only dispose of a third part of their assets so they do not slander their other sons. ADB, Quinta de Real, Requerimento do Excelentíssimo Visconde do Amparo..., f. 7. 
${ }^{87}$ The sons of Valentim de Barros were legitimized by Manuel I of Portugal, in $1504 \mathrm{cf}$. Affonso, «Da verdadeira origem de algumas famílias ilustres de Braga e seu termo. XVIII Barros de São Jerónimo de Real», 12.

${ }^{88}$ The old Quinta of Real is currently property of the Congregation of Servas Franciscanas de Nossa Senhora das Graças. The manor house is still standing.

${ }^{89}$ Affonso, «Da verdadeira origem de algumas famílias ilustres de Braga e seu termo. XVIII Barros de São Jerónimo de Real», 7-9.

${ }^{90}$ This family connection between the Barros of Real and the 1st Bishop of Leiria is also found in Geografia of João de Barros João de Barros, Geographia d'entre Douro e Minho e Trasos-Montes (Porto: Câmara Municipal do Porto, 2019), 168., written in the first half of the 16th century.

${ }^{91}$ According to Manuel Severim de Faria, João de Barros, the "great", was a cousin of Friar Brás de Barros and grandson of Martim Martins de Barros. Felgueiras Gaio evidences this confluence of the lineage of these persons. See Manuel Severim de Faria, Vida de João de Barros e Indice Geral das Quatro Decadas da Sua Asia (Lisbon: Regia Officina Typografica, 1778), V-VI and Gaio, Nobiliário de Famílias de Portugal, Tomo VI:134-62.

${ }^{92}$ ADB, Quinta de Real, Requerimento do Excelentíssimo Visconde do Amparo..., ff. 4v. e 5.

${ }^{93}$ ADB, Quinta de Real, Requerimento do Excelentíssimo Visconde do Amparo..., f. 14v.

${ }^{94}$ Rosa, «A religião do século: vivências e devoções dos leigos», 461.

${ }^{95}$ From the testimonies of noble figures and the chaplain of Nossa Senhora da Graça: Gonçalo Rodrigues de Araújo, nobleman of the King's Household; Manuel de Barros, brother of Lopo de Barros, and nobleman of the King; Marcos de Barros, noble knight; Manuel Carneiro, noble knight of the Kings's Household; Doctor Bartolomeu de Faria; and, Pedro Anes do Rossio, chaplain. ADB, Quinta de Real, Requerimento do Excelentíssimo Visconde do Amparo..., ff. 16 e 16v.

${ }^{96}$ It must have been a good and honest man, who maintained the chapel and adornments very clean. ADB, Quinta de Real, Requerimento do Excelentíssimo Visconde do Amparo..., f. 11.

${ }^{97}$ Luís Cardoso (1747: 252) calls it Chapel of Anunciação. Cardoso, Diccionario geografico, ou noticia historica de todas as cidades, villas, lugares, e aldeas, rios, ribeiras, e serras dos Reynos de Portugal, e Algarve, com todas as cousas raras, que nelles se encontraõ, assim antigas, como modernas / que escreve, e offerece ao muito alto... Rey D. João V nosso senhor o P. Luiz Cardoso, da Congregaçaõ do Oratorio de Lisboa, 252.

${ }^{98}$ Archbishop D. Diogo transferred them, with authorization from King D. Manuel I (r. 14951521), to the main chancel of the cathedral in 1513 , renovated by the same prelate at that time. In 1598, Archbishop D. Frei Agostinho de Jesus separated the bones and placed them in two sarcophagi. Count D. Henrique's remains were deposited in the primitive and those of D. Teresa in another one dispensed by D. Diogo de Sousa. J. Augusto Ferreira, Fastos 
Episcopaes da Igreja Primacial de Braga (séc. III - séc. XX), Fac-simile (1932), vol. III (Famalicão: Edição da Mitra Bracarense, 2018), 383.

${ }^{99}$ Ferreira, Fastos Episcopaes da Igreja Primacial de Braga (séc. III - séc. XX), III:378.

${ }^{100}$ José Viriato Capela, As freguesias do Distrito de Braga nas Memórias Paroquiais de 1758: a construção do imaginário minhoto setecentista (Braga: Fundação para a Ciência e Tecnologia e Governo Civil de Braga, 2003), 196.

${ }^{101}$ Cavallo, Charity and Power in Early Modern Italy: Benefactors and their Motives in Turim $1547-1789,127-45$.

${ }^{102}$ ADB, Quinta de Real, Requerimento do Excelentíssimo Visconde do Amparo..., f. 15.

${ }^{103}$ Regarding the jurisdictional classification of the parties involved in the institution, see Ana Rita Saraiva da Rocha Rocha, «A assistência em Coimbra na Idade Média: dimensão urbana, religiosa e socioeconómica (séculos XII a XIV)», 374-88; Ramona Pérez Castro Pérez, «Fundaciones particulares benéfico-assistenciales y docentes en Asturias (siglos XV-XIX)» (PhD diss., Oviedo, Universidade de Oviedo, 2012), 100-102.

${ }^{104}$ ADB, Quinta de Real, Requerimento do Excelentíssimo Visconde do Amparo..., f. 11.

${ }^{105}$ ADB, Quinta de Real, Requerimento do Excelentíssimo Visconde do Amparo..., f. 8v.

${ }^{106}$ The brotherhood of São Tiago was active the Church of São Tiago of Cividade, that is, in front of the hospital's door. This brotherhood already existed in the first half of the 13th century and stayed active until 1790, when it was incorporated into the brotherhood of Santa Cruz. See Marques, «O culto de São Tiago no Norte de Portugal», 128-30; Norberto Tiago Gonçalves Ferraz, «A Morte e a Salvação da Alma na Braga Setecentista» (PhD diss., Braga, Universidade do Minho, 2014), 463-65.

107 "There is inside this city, the Hospital of São Tiago, which is visited by the prelate". ADB, Registo Geral, Censual de D. Frei Baltazar Limpo - Tombos das dignidades, conesias, mosteiros, priorados, igrejas, comendas, reitorias, vigararias e de todos os benefícios do arcebispado de Braga, 1551, n. ${ }^{\circ} 335$, f. 7. 